\title{
Epidemiologic analysis of Leptospira spp. infection among sheep in Pernambuco state, Brazil
}

\author{
Análise epidemiológica da infecção por \\ Leptospira spp. em ovinos no estado de Pernambuco, Brasil
}

\author{
Acidália Claudino Machado ${ }^{\text {* }}$, Junior Mário Baltazar de Oliveira ${ }^{1}$, José Lopes da Silva Júnior², \\ Nivaldo Aparecido de Assis ${ }^{3}$, Daniel Friguglietti Brandespim ${ }^{4}$, Luis Antonio Mathias ${ }^{3}$, \\ Rinaldo Aparecido Mota ${ }^{4}$, José Wilton Pinheiro Júnior ${ }^{4}$
}

\begin{abstract}
This study aimed to analyze epidemiological aspects and spatial characteristics of Lesptospira spp. infection among sheep in Pernambuco state, Brazil. A total of 426 samples were collected from unvaccinated animals aged 1 year or older, and submitted to Microscopic Agglutination Test (MAT). To study the risk factors, a standardized investigative survey of sheep farmers, with objective questions, was conducted to establish the general characteristics of the farm property production, reproductive management, and health plan. From 426 samples analyzed, 83 (19.5\%; CI 15.9 - 23.6\%) were positive; among them, the most prevalent serovar was Autumnalis (32.4\%). Significant differences were observed between gender $(\mathrm{OR}=0.38$; CI $0.14-0.99)$, production system $(\mathrm{OR}=2.03$; CI $1.07-3.84)$, types of herd $(\mathrm{OR}=2.28$; CI 1.39 - 3.72), absence of rodents to the grain storage $(\mathrm{OR}=0.55$; $\mathrm{CI} 0.34-0.91)$, and restriction to surface waters $(\mathrm{OR}=0.60 ;$ CI $0.37-0.99)$. Leptospira spp. infection is disseminated in sheep herds, and multiple factors can influence its occurrence. Health education programs and worker training in prevention and control of leptospirosis and other infectious diseases may be useful to reduce infection rates and economic losses caused by this disease.
\end{abstract}

KEYWORDS: epidemiology; leptospirosis; sheep industry.

\begin{abstract}
RESUMO: Objetivou-se com este estudo analisar os aspectos epidemiológicos e caracterizar espacialmente a infecção por Leptospira spp. em ovinos no estado de Pernambuco, Brasil. Para compor a amostragem do estudo, foram colhidas 426 amostras de animais com idade igual ou superior a um ano, não vacinados, e submetidas à reação de Soroaglutinaçáo Microscópica (SAM). Para o estudo dos fatores de risco, aplicou-se um questionário investigativo padronizado, constituído por perguntas objetivas ao criador, referentes às características gerais da propriedade, ao manejo produtivo, reprodutivo e sanitário. Das 426 amostras analisadas, 83 (19,5\%; IC 15,9 - 23,6\%) foram positivas; entre elas, o sorovar de maior prevalência foi o Autumnalis $(32,4 \%)$. Foram observadas diferenças significativas entre sexo $(\mathrm{OR}=0,38$; I.C. $0,14-0,99)$, sistema de criação $(\mathrm{OR}=2,03$; I.C. 1,07 - 3,84), tipo de rebanho $(\mathrm{OR}=2,28 ;$ I.C. $1,39-3,72)$, ausência do acesso de ratos a ração $(\mathrm{OR}=0,55$; I.C. $0,34-0,91)$ e restrição a águas de superfície $(\mathrm{OR}=0,60$; I.C. 0,37-0,99). A infecção por Leptospira spp. está distribuída nos rebanhos ovinos e são múltiplos os fatores que podem influenciar sua ocorrência. A implantação de programas de educação em saúde e o treinamento da mão de obra em métodos de prevenção e controle da leptospirose e outras doenças infecciosas podem ser úteis na redução dos casos de infecção e na diminuição das perdas econômicas causadas por esta enfermidade.
\end{abstract}

PALAVRAS-CHAVE: epidemiologia; leptospirose; ovinocultura.

\footnotetext{
'Laboratório de Reprodução e Doenças Infecciosas, Universidade Federal Rural de Pernambuco (UFPRE) - Garanhuns (PE), Brazil.

${ }^{2}$ Agência de Defesa e Fiscalização Agropecuária de Pernambuco (ADAGRO) - Recife (PE), Brazil.

${ }^{3}$ Laboratório de Diagnóstico de Brucelose e Leptospirose, Departamento de Medicina Veterinária Preventiva e Reprodução Animal, Faculdade de Ciências Agrárias e Veterinárias, Universidade Estadual Paulista (UNESP) - Jaboticabal (SP), Brazil.

${ }^{4}$ Laboratório de Doenças Infectocontagiosas dos Animais Domésticos, Departamento de Medicina Veterinária, UFPRE - Recife (PE), Brazil.

*Corresponding author: acidali@hotmail.com

Received on: 03/07/2014. Accepted on: 04/18/2016
} 


\section{INTRODUCTION}

Leptospirosis is an infectious disease, which determines economic losses in livestock, mainly characterized by reducing the reproductive performance in herds (Aguiar et al., 2010).

Leptospirosis in small ruminants is usually asymptomatic, which ensures the permanence of carrier animals spreading the agent in flocks, and increases the risks of infection (Herrmann et al., 2004; Araújo Neto et al., 2010).

Studies conducted by different microscopic serum agglutination techniques in some States of Brazil have detected anti-Leptospira antibody in sheep, with wide variation of anti-Leptospira prevalence and serovars (LANGONi et al., 1995; Caldas et al., 1995; 1996; Mota et al., 1999; Herrmann et al., 2004; Aguiar et al., 2010; Hashimoto et al., 2010; Higino et al., 2010, Carvalho et al., 2011; Salaberry et al., 2011; Alves et al., 2012; Martins et al., 2012).

Leptospira spp. infection in sheep has been related to environmental factors such as temperature, moisture, water and soil $\mathrm{pH}$, and presence of organic matter (Escócio et al., 2010) and/ or management-related factors, such as mixed species grazing (LANGONi et al., 1995), semi-intensive system (МотA et al., 1999), presence of carriers, not carrying out quarantine to all new arrivals to the flock (SaLABERRY et al., 2011), and animal participation in events (Alves et al., 2012).

The spatial analysis, which involves the use of environmental software, allows the visualization, exploration, and modeling of georeferenced data (Gatrell; Bailey, 1996); it also supports the creation of plans for preventive actions and health surveillance (FonZAR; LANGONI, 2012).

The sheep industry is an important production chain in the State of Pernambuco, which generates income for small farmers; however, because of the lack of studies on the occurrence of infectious diseases, it is worth highlighting that highlight leptospirosis that may cause direct and indirect losses in sheep flocks, as well as risks to public health. The present study aimed to examine epidemiological aspects and to spatially characterize the distribution of the Leptospira spp. infection among sheep in Pernambuco State, Brazil.

\section{MATERIAL AND METHODS}

This study was performed in accordance with the ethical principles of animal experimentation established by the Animal Use Ethics Committee of Universidade Federal de Pernambuco, as listed under protocol no. $018 / 2012$, issued by the president of the committee on July 13, 2012.

The cross-sectional study was conducted on 14 properties located in 11 municipalities of mesoregions Agreste Vale do Ipanema (Águas Belas, Itaíba e Pedra), semiarid of
Pernambuco-Itaparica (Carnaubeira da Penha, Floresta, Itacuruba, Tacaratu), and semiarid of Moxotó (Arcoverde, Custódia, Ibimirim, Sertânia).

A total of 426 samples were collected, providing a safety margin, considering a calculation of prevalence of Leptospira spp. infection in sheep for the sample of $33.7 \%$ (BORBA, 2004), 95\% confidence level and 5\% standard error (Thrusfield, 2005), whose minimum sampling is 344 animals.

Before the collection of biological samples, a standardized investigative survey was applied to sheep farmers, containing objective questions to establish general characteristics of the farm property production, reproductive management, and health plan, as well as to study the risk factors.

Diagnosis of serum samples was tested by Microscopic Agglutination Test (MAT; Galton et al., 1965; Cole et al., 1973), using, as antigens, 23 alive leptospiras sorovars, such as Andamana, Australis, Autumnalis, Bataviae, Bratislava, Butembo, Canicola, Castellonis, Copenhageni, Cynopteri, Hardjo, Hebdomadis, Grippotyphosa, Icterohaemorrhagiae, Javanica, Panama, Pomona, Pyrogenes, Sentot, Shermani, Tarassovi, Whitcombi, and Wolffi, grown on EllinghausenMcCullough-Johnson-Harris (EMJH) medium, transferred weekly, used after the fourth day in $\mathrm{BOD}$ incubator at $28^{\circ} \mathrm{C}$, contamination free, and self-agglutination free. Those sera showing at least $50 \%$ of agglutination of leptospires in the microscopic field from the 1:100 dilution were considered positive (Galton et al., 1965; Cole et al., 1973; Silva et al., 2012).

To identify risk factors associated with infection by Leptospira spp., an univariate analysis was conducted according to variables of interest through Pearson's chi-square test or Fisher's exact test, when necessary, and multivariate analysis by logistic regression model, considering the serological status of the animal (positive or negative) as a dependent variable. Those variables that showed statistical significance $<0.20$ were considered either independent or explanatory. The probability was stipulated to prevent possible risk factors that were not excluded from the analysis. EpiInfo 3.5.2 software was used in statistical calculations.

Prevalence was calculated using Epiinfo ${ }^{\mathrm{TM}}$ software (version 7), considering a $95 \%$ confidence interval. The properties were considered as null prevalence if there were no reagent animals; low prevalence, if the number of reagents was below $25 \%$; average prevalence, between $25 \%$ and $50 \%$, and high if the number of reagents was higher than $50 \%$. The infective serovar for the animals was determined based on the higher titer. Those cases in which there was serological coagglutination at the same titer were not considered for analysis of the serovar prevalence.

For verification of the spatial distribution of infection in the Agreste and Sertáo regions of Pernambuco, the plane coordinates obtained by georeferencing for every property by Global Positioning System (GPS) were used, which were set up to provide the positions on the coordinate plane in the Universal 
Transverse Mercator (UTM) projection, the South American Datum of 1969 system (SAD-69), corresponding to the coordinate system of Cartographic Base from study regions. For the mapping and the distribution of serovars, georeferenced data were added on the Terra View 3.1.3 software (BraziL, 2006).

\section{RESULTS}

Prevalence of anti-Leptospira antibody in sheep was $19.5 \%$ (83 of 426 properties; CI 15.9 - 23.6). In $92.8 \%$ of properties, sites of infection were found (13 of 14 properties). Analyzing the prevalence of infection by property, $3(21.4 \%)$ presented average prevalence, $10(71.4 \%)$ presented low prevalence, and $1(7.2 \%)$ presented prevalence zero (Figure 1).

The highest occurrence was the serovar Autumnalis (32.4\%), followed by Icterohaemorrhagiae (14.0\%), and Castellonis $(9.8 \%)$. However, the main serovar spread in the studied area was Icterohaemorrhagiae (Figure 2). In 12 samples, it was not possible to identify the infective serovar, as result of two or more serovar coagglutination reaction. Serovars identification and their respective titer are presented in Table 1.

Statistically significant variables on the univariate analysis of risk factors were: region ( $\mathrm{p}=0.003)$, breeding system $(p=0.016)$, gender $(p=0.0026)$, access to water $(p=0.030)$, type of herd $(\mathrm{p}<0.001)$, the presence of dogs on the property $(\mathrm{p}=0.047)$, and the absence of rodents on the grain storage $(\mathrm{p}=0.013)$. According to logistic regression (Table 2$)$, the following have been identified:

1. Risk factors: breeding system $(\mathrm{OR}=2.03 ; \mathrm{p}=0.029)$ and type of herd $(\mathrm{OR}=2.28 ; \mathrm{p}=0.001)$; and
2. Protective factors: absence of rodents to the grain storage $(O R=0.55 ; \mathrm{p}=0.020)$, restricted access to surface water $(\mathrm{OR}=0.60 ; \mathrm{p}=0.047)$, and gender $(\mathrm{OR}=0.38$; $\mathrm{p}=0.049)$.

No association was identified between occurrence of reproductive disorders (abortions, weak Cubs, retained placenta, and natimortality) and Leptospira spp. infection in sheep $(\mathrm{p}=0.122)$.

\section{DISCUSSION}

The sero prevalence observed was similar to that reported by SalaberRY et al. (2011) in Minas Gerais and Marinho et al. (2012) in São Paulo; however, in comparison to the previous records in the State of Pernambuco, it was found that the results of this study are lower than those described by МотA et al. (1999) and Borba (2004), which reported 57.8\% and 33.7\% of prevalence, respectively. MотA et al. (1999) used samples collected in Recife, Zona da Mata, and Agreste, not including the semiarid, whereas sampling plans carried out by BORBA (2004) covered metropolitan region of Recife, the state Zona da Mata, Agreste, and semiarid of Pernambuco. However, the samples from the Agreste area were only collected in Gravatá, and, from the semiarid, in Floresta. The difference between the results obtained in this study and those registered previously in the State can be related to the geographical regions, sampling plans, and control measures adopted in the properties.

The large number of sites of infection recorded (92.8\%) is in agreement with findings from other studies carried out in

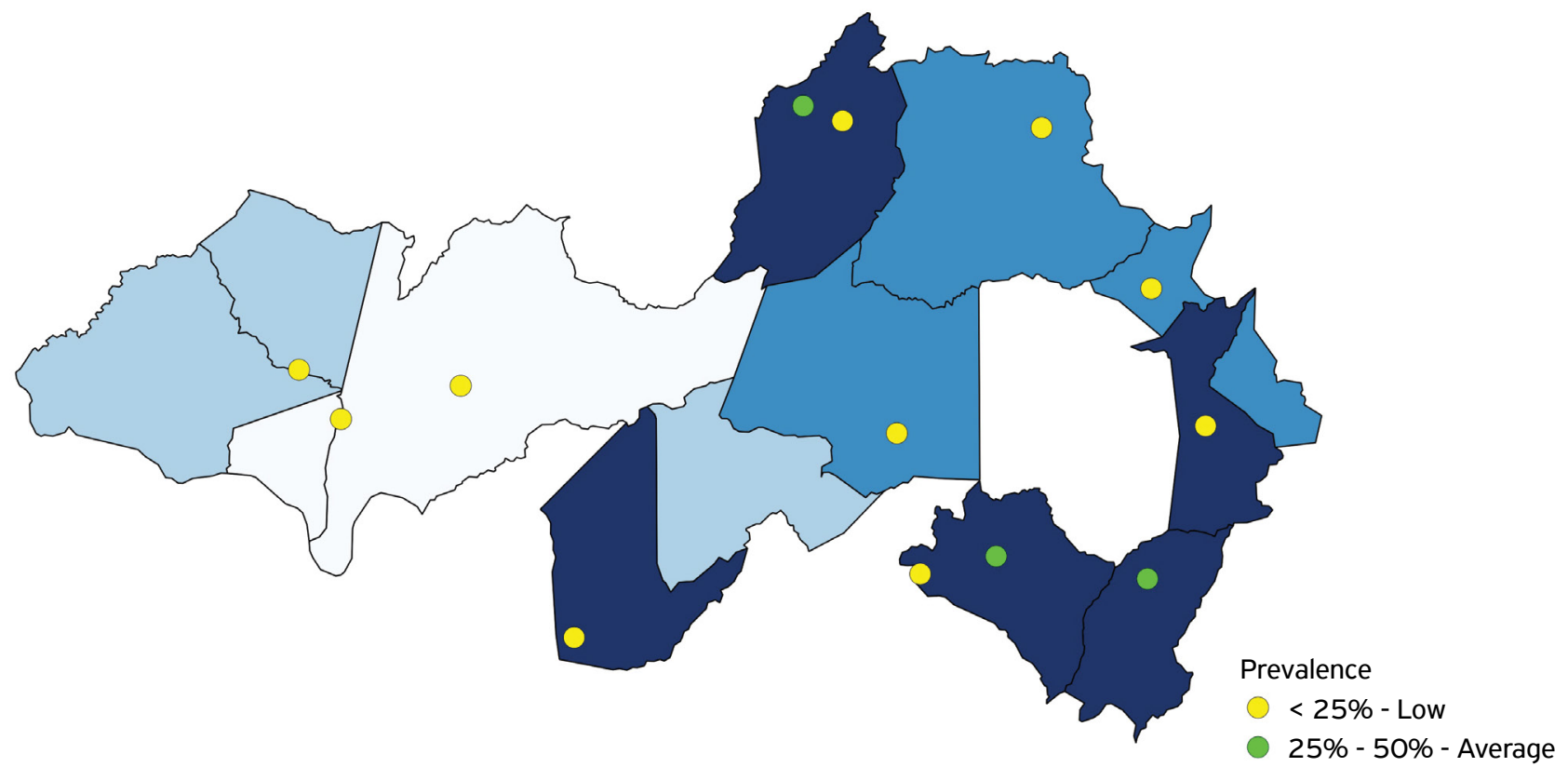

Figure 1. Prevalence of Leptospira spp. among sheep in Pernambuco state, 2012. 


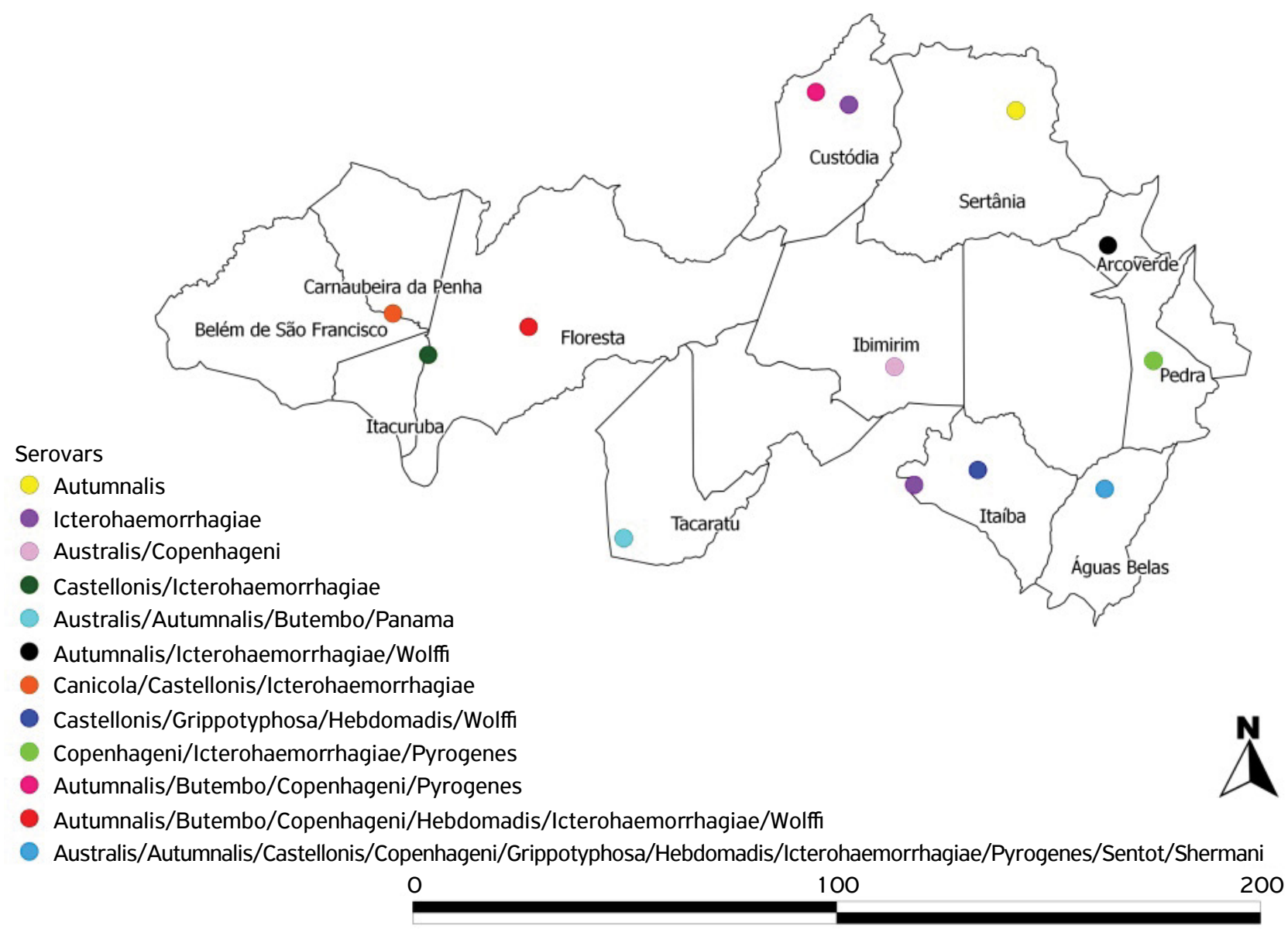

Figure 2. Distribution of Leptospira spp. in properties with seropositive sheep in Pernambuco state, 2012.

Table 1. Distribution of Leptospira spp. serovars among sheep in Pernambuco state, Brazil.

\begin{tabular}{|c|c|c|c|c|c|c|c|}
\hline \multirow[b]{2}{*}{ Serovars } & \multicolumn{6}{|c|}{ Titer } & \multirow[b]{2}{*}{ Total } \\
\hline & $\begin{array}{c}1: \\
100\end{array}$ & $\begin{array}{c}1: \\
200\end{array}$ & $\begin{array}{c}1: \\
400\end{array}$ & $\begin{array}{c}1: \\
800\end{array}$ & $\begin{array}{c}1: \\
3.200\end{array}$ & $\begin{array}{c}1: \\
6.400\end{array}$ & \\
\hline Australis & 1 & - & - & - & - & - & 1 \\
\hline Autumnalis & 18 & 3 & 1 & 1 & - & - & 23 \\
\hline Butembo & 2 & 2 & - & - & - & - & 4 \\
\hline Castellonis & 4 & 3 & - & - & - & - & 7 \\
\hline Copenhageni & 2 & 2 & - & - & - & - & 4 \\
\hline Grippotyphosa & 3 & - & - & - & 1 & - & 4 \\
\hline Hebdomadis & 3 & - & - & - & - & 1 & 4 \\
\hline $\begin{array}{l}\text { Icterohamorr- } \\
\text { hagiae }\end{array}$ & 9 & 1 & - & - & - & - & 10 \\
\hline Panama & - & 1 & - & - & - & - & 1 \\
\hline Pyrogenes & 1 & 2 & - & - & - & - & 3 \\
\hline Sentot & 1 & 1 & - & 1 & - & - & 3 \\
\hline Shermani & - & 1 & - & - & - & - & 1 \\
\hline Wolffi & 4 & 1 & 1 & - & - & - & 6 \\
\hline Total & 48 & 17 & 2 & 2 & 1 & 1 & 71 \\
\hline
\end{tabular}

Table 2. Logistic regression of risk factor associated with Leptospira spp. infection among sheep in Pernambuco state, 2012.

\begin{tabular}{lccc} 
Variable & $\mathrm{p}$-Value & $\mathrm{OR}^{\mathrm{a}}$ & $95 \% \mathrm{Cl}^{\mathrm{b}}$ \\
$\begin{array}{l}\text { System } \\
\text { (semi-intensive/extensive) }\end{array}$ & 0.029 & 2.03 & $1.07-3.84$ \\
\hline Herd (open/closed) & 0.001 & 2.28 & $1.39-3.72$ \\
\hline $\begin{array}{l}\text { Access of rodents to grain } \\
\text { (no/yes) }\end{array}$ & 0.020 & 0.55 & $0.34-0.91$ \\
\hline Surface water (no/yes) & 0.047 & 0.60 & $0.37-0.99$ \\
\hline Gender (male/female) & 0.049 & 0.38 & $0.14-0.99$ \\
\hline
\end{tabular}

different regions of the country, as reported by HERRMAN et al. (2004) in Rio Grande do Sul (83.09\%), Aguiar et al. (2010) in Rondônia (80\%), Escócio et al. (2010) in São Paulo (100\%), Genovez et al. (2011) in São Paulo (100\%), Moraes et al. (2012) in Pará (75.0\%), and Salaberry et al. (2011) in Minas Gerais.

Variation in the prevalence among properties may be related to factors such as the production system (Herrman et al., 2004), management (Higino et al., 2012), topography, temperature, moisture, precipitation, and contact with other wild animals 
or domestic carriers, which contribute to the occurrence rate of infection (Aguiar et al., 2010; Araújo Neto, et al., 2010).

The serovar Autumnalis, found in $32.4 \%$ of the animals, has been identified mainly in the Brazilian northeast (BORBA, 2004; Higino et al., 2010; Carvalho et al., 2011; Adams et al., 2012). In 2007, Leptospira nouguchii species was isolated in apparently healthy sheep, showing that these animals can act as hosts for the serovar Autumnalis (SiLva et al., 2007). The serovar Autumnalis was also identified in previous studies as the most frequent carried out in dogs in the city of Patos, $\mathrm{PB}$ (Batista et al., 2005) and Monte Negro, RO (Aguiar et al., 2007), coinciding with the results found in sheep in the same locations by Higino et al. (2010) and Aguiar et al. (2010), respectively. It is possible that interspecies relationship has contributed to the agent's maintenance and the transmission between species, showing that studies are needed to identify which species acts as maintenance hosts.

The next most prevalent serovar Icterohaemorrhagiae $(14.0 \%)$, and also the most widespread in the studied area, is mainly related to the presence of rodents, which reinforces the need for the implementation of programs to control and eliminate rats on properties (Araújo Neto et al., 2010).

Semi-intensive was identified as the system with the higher prevalence among the production systems (21.9\%), showing a risk of infection $(\mathrm{OR}=2.03)$. The same result was reported by MотA et al. (1999) in Bezerros, PE. It is possible that the high population density in the semi-intensive system contributes to agent spread through livestock production areas, resulting in a greater challenge for infection control. Promoting routine sanitation and hygiene practices in the properties can contribute in the reduction of the prevalence of leptospirosis in livestock production.

This study identified that in herds where rodents did not have access to grain storage, the risk of infection was lower $(\mathrm{OR}=0.55)$. Therefore, indoors and suspended grain storage are strongly recommended, to avoid access of rodents (BRAZIL, 2002 FIOCRUZ, 2004), and, consequently, cases of leptospirosis.

The variable gender was also significant for males $(\mathrm{OR}=0.38)$, considered as a protective factor. It was observed that positive males ( 5 of 54 properties) belonged to four different herds, 100\% of which had open and semi-intensive systems. Although the gender variable has been identified as a protective factor, detailed studies are necessary to verify gender-related predisposition, considering that Leptospira spp. infection in sheep is closely associated to sanitation and hygienic management.

The present study also found that animals in closed sheep flock have higher chances of infection $(\mathrm{OR}=2.28)$. Closed herds, in which there were no new animal arrivals from other properties, were raised in a semi-intensive system $(72.5 \%)$, which may be related to the findings in this study, as the system was also considered a risk factor. Because of the possibility of infection by vaginal or semen secretion (LILENBAUM et al., 2008) and placental transmission (Guimaráes et al., 1982 ; 19 of 83 properties), using ram and ewes without proper knowledge of their health status and without preventive antibiotic therapy may have contributed to the infection of the offspring and the increase in frequency for this variable.

In this study, herds in which animals do not had access to stagnant water showed a lower risk of infection $(\mathrm{OR}=0.60)$. According to Andre-Fontain; Ganiere (1990), water is the most important epidemiological factor for leptospirosis. Surface waters can remain contaminated for several weeks under ideal conditions (Brod; Fehlberg, 1992).

In general, it was observed that some of the risk factors identified were related to the production system and the environment's sanitation and hygienic management. Due to the epidemiological complexity of leptospirosis, interventionist programs should be implemented with the purpose of interfere in the life cycle of the bacteria, and its components (Brod; Fehlberg, 1992).

\section{CONCLUSION}

The occurrence of leptospirosis in sheep flocks can be influenced by multiple factors. It is important to highlight that this is the first spatial characterization of Leptospira spp. infection among sheep in Pernambuco state, and these data provide alternative plans for prevention and control of leptospirosis infection in order to reduce significantly economic losses.
AGUIAR, D.M.; CAVALCANTE, G.T.; MARVULO, M.F.V.; SILVA, J.C.R. PINTER, A.; VASCONCELLOS, S.A.; MORAIS, Z.M.; LABRUNA, M.B.; CAMARGO, L.M.A.; GENNARI, S.M. Fatores de risco associados à ocorrência de anticorpos anti-Leptospira spp. em cães do município de Monte Negro, Rondônia, Amazônia Ocidental Brasileira. Arquivo Brasileiro de Medicina Veterinária e Zootecnia, v.59, n. 1, p.70-76, 2007.

AGUIAR, D.M.; CAVALCANTE, G.T.; VASCONCELLOS, S.A.; SOUZA, G.O.; LABRUNA, M.B.; CAMARGO, L.M.A.; GENNARI, S.M. Anticorpos
anti-Leptospira spp. em ovinos do município de Monte Negro, estado de Rondônia. Arquivos do Instituto Biológico, v.77, n.3, p.529-532, 2010.

ALVES, C.J.; ALCINO, J.F.; FARIAS, A.E.M.; HIGINO, S.S.S.; SANTOS, F.A., AZEVEDO, S.S.; COSTA, D.F.; SANTOS, C.S.A.B. Caracterização epidemiológica e fatores de risco associados à leptospirose em ovinos deslanados do semiárido brasileiro. Pesquisa Veterinária Brasileira, v.32, n.6, p. 523-528, 2012. 
ANDRE-FONTAINE, G.; GANIERE, J.P. New topics on leptospirosis. Comparative Immunology, Microbiology \& Infectious Diseases, v.13, n.3, p.163-168, 1990.

ARAÚJO NETO, J.O; ALVES, C.J.; AZEVEDO, S.S.; SILVA, M.L.C.R.; BATISTA, C.S.A. Soroprevalência da leptospirose em caprinos da microrregião do Seridó Oriental, Estado do Rio Grande do Norte, Brasil, e pesquisa de fatores de risco. Brazilian Journal of Veterinary Research and Animal Science, v.47, n.2, p.150155, 2010.

BATISTA, C.S.A.; ALVES, C.J.; AZEVEDO, S.S.; VASCONCELLOS, S.A.; MORAIS, Z.M.; CLEMENTINO, I.J.; ALVES, F.A.L.; LIMA, F.S.; ARAÚJO NETO, J.O. Soroprevalência e fatores de risco para a leptospirose em cães de Campina Grande, Paraíba. Arquivo Brasileiro de Medicina Veterinária e Zootecnia, v.57, p.179-185, 2005.

BRASIL. Fundação Nacional de Saúde. Manual de controle de roedores. Brasília: Ministério da Saúde, Fundação Nacional de Saúde, 2002.

BRASIL. Ministério de Ciência e Tecnologia. Instituto Nacional de Pesquisas Espaciais. TerraView ver. 3.1.3, 2006. Available from: <http://www.dpi.inpe.br/terraview/index.php>. Accessed on: $01 / 06 / 2012$.

BORBA, M.A.C. Estudo soroepidemiológico da leptospirose em caprinos e ovinos do Estado de Pernambuco. Dissertação (Mestrado - Ciências Veterinárias) - Programa de Pós-Graduação em Ciência Veterinária, Universidade Federal Rural de Pernambuco, Recife, 2004.

BROD, C.S.; FEHLBERG, M.F. Epidemiologia da leptospirose em bovinos. Ciência Rural, v.22, n.2, p.239-245, 1992.

CALDAS, E.M.; VIEGAS, E.A.; VIEGAS, S.A.R.A.; REIS, R.S. Aglutininas anti-Leptospira em ovinos e caprinos na região Nordeste do Estado da Bahia. Arquivos da Escola de Veterinária da Universidade Federal da Bahia, v.18, n. 1, p.126-140, 1995/96.

CARVALHO, S.M.; GONÇALVES, L.M.F.; MACEDO, N.A.; GOTO, H.; SILVA, S.M.M.S.; BARRADAS, A.L.B.; KANASHIRO, E.H.Y.; COSTA, F.A.L. Infecção por leptospiras em ovinos e caracterização da resposta inflamatória renal. Pesquisa Veterinária Brasileira, v.31, n.8, p.637-642, 2011.

COLE JR., J.R.; SULZER, C.R.; PURSELL, A.R. Improved Microtechnique for the Leptospiral Microscopic Agglutination Test. Applied Microbiology, v.25, n.6, p.976-980, 1973.

ESCÓCIO, C., GENOVEZ, M.E.; CASTRO, V.; PIATTI, R.M.; GABRIEL, F.H.L.; CHIEBAO, D.P.; AZEVEDO, S.S.; VIEIRA, S.R.; CHIBA, M. Influência das condições ambientais na transmissão da leptospirose entre criações de ovinos e bovinos da região de Sorocaba, SP. Arquivos do Instituto Biológico, v.77, n.3, p.371-379, 2010.

FIOCRUZ. Fundação Oswaldo Cruz. Controle de roedores. Recomendações à população. 2004. Available from: http://www.fiocruz.br/ccs/cgi/cgilua.exe/sys/start. htm? infoid $=1007 \&$ sid $=12$. Accessed on: 03 jun 2013.

FONZAR, U.J.V.; LANGONI, H. Análise geográfica da ocorrência da leptospirose em humanos e em cães na cidade de Maringá,
Paraná, Brasil. Revista da Sociedade Brasileira de Medicina Tropical, v.45, n. 1, p.100-105, 2012.

GALTON M.M.; SULZER, C.R.; SANTA ROSA, C.A.; FIELDS, M.J. Application of a Microtechnique to the Agglutination Test for Leptospiral Antibodies. Applied Microbiology, v.13, n.1., p.8185, 1965.

GATRELL, A.C.; BAILEY, T.C. Interactive spatial data analysis in medical geography. Social Science \& Medicine, v.42, n.6, p. 843-855, 1996.

GENOVEZ, M.E.; ESCÓCIO, C.; CASTRO, V.; GABRIEL, F.H.L.; CHIEBAO, D.P.; AZEVEDO, S.S. Fatores de risco associados à infecção pela Leptospira spp. sorovarhardjo em rebanhos exclusivos de ovinos e nos consorciados com bovinos. Arquivos do Instituto Biológico, v.78, n.4, p.587-592, 2011.

GUIMARÃES, M.C.; CÔRTES, J.A.; VASCONCELLOS, S.A.; ITO, F.H. Epidemiologia e controle da leptospirose em bovinos, papel do portador e seu controle terapêutico. Comunicação Científica Faculdade de Medicina Veterinária e Zootecnia da Universidade de São Paulo, v.6/7, n.1/4, p.21-34, 1982/83.

HASHIMOTO, V.Y.; GARCIA, J.L.; SPOHR, K.A.H.; DA SILVA, F.G.; ALVES, L.A.; DE FREITAS, J.C. Prevalência de anticorpos contra Leptospira spp. em bovinos, caninos, equinos, ovinos e suínos do município de Jaguapitã, Estado do Paraná, Brasil. Arquivos dos Instituto Biológico, v.77, n.3, p.521-524, 2010.

HERRMANN, G.P.; LAGE, A.P.; MOREIRA, E.C.; HADDAD, J.P.A.; RESENDE, J.R.; RODRIGUES, R.O.; LEITE, R.C. Soroprevalência de aglutininas anti-Leptospira spp. em ovinos nas Mesorregiões Sudeste e Sudoeste do Estado Rio Grande do Sul, Brasil. Ciência Rural, v.34, n.2, p.443-448, 2004.

HIGINO, S.S.S.; AZEVEDO, S.S., ALVES, C.J.; FIGUEIREDO, S.M.; SILVA, M.L.C.R.; BATISTA, C.S.A. Frequência de leptospirose em ovinos abatidos no município de Patos, Paraíba. Arquivos do Instituto Biológico, v.77, n.3, p.525-527, 2010.

HIGINO, S.S.S., SANTOS, F.A.; COSTA, D.F.; SANTOS, C.S.A.B.; SILVA, M.L.C.R.; ALVES, C.J.; AZEVEDO, S.S. Flock-level risk factors associated with leptospirosis in dairy goats in a semiarid region of Northeastern Brazil. Preventive Veterinary Medicine, v.109, n.1-2, p.158-161, 2012. Available from: <http://dx.doi. org/10.1016/j.prevetmed.2012.09.005>. Accessed on: 01 fev. 2013.

LANGONI, H.; MARINHO, M.; BALDANI, S.; SILVA, A.V.; CABRAL, K.G.; SILVA, E.D. Pesquisa de aglutininas anti-leptospiras em soros ovinos do Estado de São Paulo, Brasil, utilizando provas de macroaglutinação em placa e soroaglutinação microscópica. Revista Brasileira de Medicina Veterinária, v.17, n.6, p.264-268, 1995.

LILENBAUM, W.; VARGES, R.; BRANDÃO, F.Z.; CORTEZ, A.; DE SOUZA, S.O.; BRANDÃO, P.E.; RICHTZENHAIN, L.J.; VASCONCELLOS, S.A. Detection of Leptospira spp. in semen and vaginal fluids of goats and sheep by polymerase chain reaction. Theriogenology, v.69, n.7, p.837-842, 2008.

MARINHO M.; MENDES, L.C.N.; KANETO, C.N.; TAPARO, C.V.; BERNARDES, J.O.R.; LOMBARDI, A.L.; PERRI, S.H.V.; BALDOSSO, 
A.B.; RIBEIRO, M.M. Perfil de aglutininas anti-Leptospira e antiBrucella e condições sanitárias de ovinos da região noroeste do estado de São Paulo, Brasil. Veterinária e Zootecnia, v.19, n.4, p.593-600, 2012.

MARTINS, G.; PENNA, B.; HAMOND, C.; LEITE, R.C.; SILVA, A.; FERREIRA, A.; BRANDÃO, F.; OLIVEIRA, F.; LILENBAUM, W. Leptospirosis as the most frequent infectious disease impairing productivity in small ruminants in Rio de Janeiro, Brazil. Tropical Animal Health and Production, v.44, p.773-777, 2012.

MOTA, R.A.; CUNHA, E.L.P.; GOTTSHALK, S.; SILVA, A.C.C.; SILVA, A.V.; LANGONI, H. Pesquisa de aglutininas anti-leptospiras em soros de ovinos no Estado de Pernambuco-Brasil. Pesquisa em Foco, v.7, n.9, p.107-114, 1999.

MORAES, C.C.G.; GUERREIRO, A.N.; KURODA, R.B.S.; SOUZA, V.A.F.; MENESES, A.M.C.; VASCONCELLOS, S.A. Inquérito sorológico para leptospirose em rebanhos de ovinos no município de Igarapé-Açu, Estado do Pará. Revista de Ciências Agrárias, v.55, n. 1, p.58-60, 2012.
SALABERRY; S.R.S.; CASTRO, V.; NASSAR; A.F.C.; CASTRO, J.R.; GUIMARÃES, E.C.; LIMA-RIBEIRO, A.M.C. Seroprevalence and risk factors of antibodies against Leptospira spp. in ovines from Uberlândia municipality, Minas Gerais State, Brazil. Brazilian Journal of Microbiology, v.42, n.4, p.14271433, 2011.

SILVA, E.F.; BROD, C.S.; CERQUEIRA, G.M.; BOURSCHEIDT, D.; SEYFFERT, N.; QUEIROZ, A.; SANTOS, C.S.; KO, A.I.; DELLAGOSTIN, O.A. Isolation of Leptospira noguchii from sheep. Veterinary Microbiology, v.121, n.1-2, p.144-149, 2007.

SILVA, F.J.; CONCEIÇÃO, W.F.L.; FAGLIARI, J.J.; GIRIO, R.J.S.; DIAS, R.A.; BORBA, M.R.; MATHIAS, L.A. Prevalência e fatores de risco de leptospirose bovina no Estado do Maranhão. Pesquisa Veterinária Brasileira, v.32, p.303$312,2012$.

THRUSFIELD, M. Veterinary Epidemiology. $3^{\text {th }}$ ed. Oxford: Blackwell, 2005. 